\title{
Circulating fibronectin and fibronectin receptor in children with pertussis
}

\author{
D Torre, M Giola, C Zeroli, R Martegani, G Bonetta, G Ferrario
}

\begin{abstract}
Aim-To determine concentrations of fibronectin and fibronectin receptor in children with pertussis.

Methods-Concentrations of circulating fibronectin and serum fibronectin receptor were detected in eight children affected by pertussis, eight children with acute upper or lower respiratory tract infections, and in 14 healthy control children. The single radial immunodiffusion technique and a solid phase enzyme immunoassay were used to detect circulating serum concentrations of fibronectin and fibronectin receptor.

Results-On admission, a significant decrease in fibronectin was detected in children with pertussis $(p=0.0006)$. Significant and decreased concentrations of fibronectin were also observed in children with upper or lower respiratory tract infections $(p=0.0002)$. On the other hand, serum fibronectin receptor concentrations were significantly increased in patients with pertussis, whereas patients with upper or lower respiratory tract infections had normal circulating fibronectin receptor concentrations. Conclusions-Fibronectin deficiency in children with pertussis may be related to diffusion and deposition of this protein in bronchial and alveolar spaces to limit infection, while increased fibronectin receptor concentrations are probably the expression of $T$ cell activation and cellmediated immunity during Bordetella pertussis infection.
\end{abstract}

(F Clin Pathol 1994;47:793-795)

Bordetella pertussis, the causative agent of pertussis, is a non-invasive pathogen which attaches to respiratory epithelial cells and produces disease through the action of several bacterial toxins, including pertussis toxin. ${ }^{12}$ Three Bordetella pertussis proteins, filamentous haemagglutinin, pertussis toxin, and pertactin, have been implicated as adhesins. ${ }^{34}$ Lawson found that in patients dying before the fifth week of illness $B$ pertussis could be isolated more often from alveoli than from trachea or bronchi. ${ }^{5}$ Cheers and Gray observed that $B$ pertussis persisted within the respiratory tract and, in particular, the alveolar macrophages of experimentally infected mice. ${ }^{67}$ Several other studies have shown that $B$ pertussis may have invasive capabilities and the ability to survive intracellularly in human macrophages, ${ }^{8}$ and in human polymorphonuclear leucocytes. ${ }^{9}$ The intracellular localisation of $B$ pertussis may be an important survival mechanism in the disease process. Fibronectin is a $\mathbf{4 4 0}$ kilodalton glycoprotein, which is present both in soluble form in plasma and other body fluids. ${ }^{10}$ Although many cell types can synthesise and secrete fibronectin, most, if not all, circulating fibronectin is produced by hepatocytes. ${ }^{11}$ Fibronectin is active in several cellular processes, such as cell adhesion, cell migration, and phagocytosis. ${ }^{12} 13$ Fibronectin also interacts with several bacteria, including Staphylococcus aureus, ${ }^{14}$ Streptococcus pyogenes ${ }^{15}$ and Gram negative bacilli (Pseudomonas aeruginosa, Escherichia coli, and Serratia marcescens). ${ }^{1617}$ Under normal conditions, lungs contain fibronectin in the basal lamina of alveolar capillaries and epithelium, and in pleural and alveolar lining fluid. ${ }^{18}$ Much of the fibronectin detected in injured lungs is of plasma origin. ${ }^{18}$ However, fibronectin is also locally synthesised by activated alveolar macrophages, endothelial cells, and alveolar type 2 and bronchial epithelial cells in injured pulmonary tissues. ${ }^{19}$ Fibronectin receptor is a member of the integrin family of cell adhesion molecule receptors. Specific adhesive interaction between cells and substrata are crucial to a wide range of biological processes, including cell motility, phagocytosis, and immune response. ${ }^{2021}$

\section{Methods}

From February 1989 to March 1992 eight of the 13 children admitted to our hospital for suspected pertussis were identified as having a positive $B$ pertussis culture, or direct fluorescence test result, or characteristic clinical findings of pertussis and a contact with a culture proved pertussis. Supportive treatments and antibiotics were given to all patients. Eight children who also had acute bacterial bronchitis or pneumonia were included in this study. Fourteen healthy children served as controls. Informed consent was obtained from the parents of all subjects.

Blood samples from patients were collected at admission, and seven and 15 days later. Blood specimens were immediately centrifuged and samples were frozen at $-20^{\circ} \mathrm{C}$ until assayed.

Fibronectin concentrations were determined using the single radial immunodiffusion technique with a monospecific antiserum 
directed against human fibronectin (The Binding Site Ltd, Birmingham, England). The assay requires a $5 \mu \mathrm{l}$ serum sample. The plates were left at $25^{\circ} \mathrm{C}$ for 96 hours and the diameters of the resulting precipitation rings was measured.

Fibronectin receptor concentrations were determined in the sera of our patients using a solid enzyme immunoassay, based on a sandwich method that uses two mouse monoclonal anti-fibronectin receptor antibodies (Takara Shuzo, Kyoto, Japan). The amount of fibronectin receptor was quantitated by measuring the absorbance (at $492 \mathrm{~nm}$ ) in a microtitre plate reader.

Data are expressed as mean (SD). Differences were evaluated for significance by using the Mann-Whitney $U$ test, and the ANOVA test, when appropriate. A p value of less than 0.05 was considered significant.

\section{Results}

Table 1 shows the clinical and demographic characteristics of the patients evaluated in this

Table 1 Clinical and demographic characteristics of the study population

\begin{tabular}{lll}
\hline & Sex (M/F) & Age (years) \\
\hline $\begin{array}{l}\text { Controls (n 14) } \\
\text { Patients with respiratory }\end{array}$ & $8 / 6$ & $2.9(3 \cdot 5)$ \\
$\quad$ tract infections (n 8) & $4 / 4$ & $3.6(2 \cdot 2)$ \\
Patients with pertussis (n 8) & $3 / 5$ & $1.5(1.3)$ \\
\hline
\end{tabular}

Table 2 Circulating fibronectin concentrations in the sera of children with pertussis and with acute upper or lower respiratory tract infections on admission

\begin{tabular}{|c|c|c|}
\hline & Fibronectin $\mu g / m l$ & p Value ${ }^{\star}$ \\
\hline Controls (n 14) & $334.5(36 \cdot 1)$ & \\
\hline $\begin{array}{l}\text { Patients with } \\
\text { respiratory tract } \\
\text { infections (n } 8)\end{array}$ & $220.5(83.7)$ & 0.0002 \\
\hline Patients with pertussis & $266.6(39.9)$ & 0.0006 \\
\hline
\end{tabular}

Table 3 Circulating fibronectin in six children with pertussis seven and 15 days after admission to hospital

\begin{tabular}{llll}
\hline \multirow{4}{*}{ Patient } & \multicolumn{3}{l}{ Fibronectin $(\mu g / m l)$} \\
\cline { 2 - 4 } & 0 & 7 & 15 days \\
\hline 1 & 270 & 240 & 280 \\
2 & 220 & 260 & 255 \\
3 & 215 & 180 & 320 \\
4 & 290 & 320 & 310 \\
5 & 315 & 340 & 318 \\
6 & 228 & 290 & 275 \\
Mean (SD) values & $256 \cdot 3(41 \cdot 4)$ & $271 \cdot 6(58 \cdot 1)$ & $293 \cdot 0(26 \cdot 7)$
\end{tabular}

ANOVA test: $p=0.3742$

Table 4 Fibronectin receptor concentrations in the sera of children with pertussis and with acute upper or lower respiratory tract infections on admission

\begin{tabular}{|c|c|c|}
\hline Patients & $\begin{array}{l}\text { Fibromectin receptor } \\
\text { ng/ml }\end{array}$ & p Value* \\
\hline $\begin{array}{l}\text { Controls (n 14) } \\
\text { Patients with respiratory }\end{array}$ & $139 \cdot 8(58 \cdot 2)$ & \\
\hline $\begin{array}{l}\text { tract infections (n 8) } \\
\text { Patients with pertussis (n 8) }\end{array}$ & $\begin{array}{l}122.9(52 \cdot 7) \\
576.6(336 \cdot 7)\end{array}$ & $\begin{array}{l}\text { NS } \\
0.0003\end{array}$ \\
\hline
\end{tabular}

study. Table 2 indicates the fibronectin concentrations in eight children with pertussis. As can be seen, a significant decrease in fibronectin was observed in these patients $(p$ $=0.0006$ ). Patients with acute upper or lower respiratory tract infections had decreased fibronectin concentrations as well ( $p=$ 0.0002 ).

Table 3 shows the fibronectin concentrations in six children with pertussis, who were followed up for 15 days. As shown, a moderate but not significant increase in fibronectin concentrations was noted 15 days after admission (ANOVA test: $\mathrm{p}=0.3742$ ). Table 4 shows the serum concentrations of fibronectin receptor in patients with pertussis and in those with acute upper or lower respiratory tract infections. A significant increase in serum fibronectin receptor concentrations was observed in patients with pertussis $(p=$ 0.0003 ). On the other hand, patients with acute respiratory tract infections had normal serum fibronectin receptor concentrations.

\section{Discussion}

The results of our study show that fibronectin concentrations were significantly reduced in children with pertussis; in contrast, serum fibronectin receptor concentrations were increased in the same patients. Monocytes and macrophages bind fibronectin and such proteins have been reported to enhance the phagocytosis of gelatin-coated erythrocytes. ${ }^{22}$ The decreased fibronectin concentrations observed in our patients could be related to opsonisation activity with a probable consumption of fibronectin itself. On the other hand, fibronectin may have a role in the pulmonary colonisation and infection caused by $B$ pertussis. During $B$ pertussis infection, in view of local abundance of fibronectin in bronchial and alveolar spaces, binding of fibronectin to $B$ pertussis might assist attachment to bronchial and alveolar epithelial cells. Fibronectin, acting as an opsonin, may bind $B$ pertussis through its adhesive sequence in bronchial and alveolar spaces. Such opsonic binding can lead to consumption of fibronectin in order to stimulate phagocytosis and killing of $B$ pertussis and thus to limit colonisation and consequent infection. In this case fibronectin deficiency in children with pertussis as well as in those with acute bacterial respiratory tract infection may be due to diffusion and deposition of fibronectin into areas of inflammation, and in particular, within bronchial and alveolar spaces, to limit or block bacterial infection.

Fibronectin receptor belongs to an "integrin superfamily", and as a serum integrin, is involved in specific adhesive interaction between mononuclear cells and extracellular matrix. ${ }^{23}$ Fibronectin receptor has also been identified as very late antigen-5 (VLA-5) of the VLA integrin family. VLA-5 integrins are expressed in activated human $T$ cells as well as in many other cell types, including monocyte/macrophages. In recent years the role of cell mediated immunity in protection against 
$B$ pertussis infection has been investigated thoroughly. Several investigators have shown that a strong $\mathrm{T}$ cell mediated reactivity to $B$ pertussis bacteria develops in mice after aerosol infection..$^{25}$ In particular, $B$ pertussis specific $T$ cells induced by infection in mice are confined to the CD4 positive $\mathrm{T}$ cell subpopulation. ${ }^{26}$ Increased serum concentrations of circulating fibronectin receptor in children with pertussis may be related to expression and release of such integrin from human $T$ cells activated by whole $B$ pertussis bacteria, or its components, including pertussis toxin, filamentous haemagglutinin, agglutinogens and pertactin.

In conclusion, the multiple biological functions of fibronectin suggest a role for it as a defence protein in the early phase of infection. In contrast, due to its interaction with microorganisms, fibronectin is also potentially important in the adherence of bacteria to epithelial cells and in the establishment of respiratory infection. However, further studies are needed to elucidate the role of fibronectin in binding $B$ pertussis, allowing alveolar macrophages to phagocytise and kill efficiently the organism.

We thank Drs Giancarlo Lorusso and Roberto Giorgetti of the Division of Paediatrics, General Hospital, Tradate (Italy), for providing clinical samples.

1 Tuomanen E. Bordetella pertussis adhesins. In: AC Wardlaw and R Parton, eds. Pathogenesis and immunity in pertussis. Chichester: John Wiley and Sons, 1988:75-94.

2 Relman DA, Wright SD, Falkow S, Saukkonen K, Tuomanen E. Mechanisms of Bordetella pertussis adherence to ciliated respiratory cells and human macrophages. Proceedings of the sixth international symposium on pertussis. Bethesda, Maryland: Department of sium on pertussis. Bethesda, Maryland:

3 Tuomanen $E$. Towbin $H$, Rosenfelder $G$, et al. Receptor analogs and monoclonal antibodies that inhibit adherence of Bordetella pertussis to human ciliated respiratory ence of Bordetella pertussis to human ciliated

4 Charles IG, Dougan G, Pickard D, et al. Molecular cloning and characterization of protective outer membrane protein P69 from Bordetella pertussis. Proc Nat Acad Sci USA 1989;86:3554-8.

5 Lawson GM. Studies on Bacillus pertussis. [ $\mathrm{PhD}$ thesis.] Harvard School of Public Health, Boston, Massachusetts, 1967.

6 Cheers C, Gray DF. Macrophage behaviour during the complaisant phase of murine pertussis. Immunology 1969;17:875-87.
7 Gray DF, Cheers C. The steady state in cellular immunity. II. Immunological complaisance in murine pertussis. Aust ₹ Exp Biol Med Sci 1967;45:417-26.

8 Friedman RL, Nordensson K, Wilson L, Akporiaye ET Yocum DE. Uptake and intracellular survival of Bordetella pertussis in human macrophages. Infect Bordetella pertussis in

9 Steed LL, Setareh M, Friedman RL. Intracellular survival of virulent Bordetella pertussis in human polymorphonuclear leukocytes. F Leukocyte Biol 1991;50:321-30.

10 Mosher DF. Physiology of fibronectin. Ann Rev Med 1984;35:561-75.

11 Tamkun JW, Hynes RO. Plasma fibronectin is synthesized and secreted by hepatocytes. F Biol Chem 1983;258: 4641-7.

12 Hynes RO. Fibronectins. New York: Springer Verlag, 1990;365-74.

13 Hynes RO. Molecular biology of fibronectin. Ann Rev Cell Biol 1985;1:67-90.

14 Kuusela P. Fibronectin binds to Staphylococcus aureus. Nature 1978;276:718-20.

15 Beachy EH, Courtney HS. Bacterial adherence: the attachment of group A streptococci to mucosal surfaces. Rev Infect Dis 1987;9:S475-S81.

16 Vercelloti GM, Lussenhop D, Peterson PK, Furcht LT, McCarthy JB, Jacob HS. Bacterial adherence to fibronectin and endothelial cells: a possible mechanism for bacterial tissue tropism. I Lab Clin Med 1984;103: $34-43$.

17 Scheld WM, Strunk RW, Balian G, Calderone RA Microbial adhesion to fibronectin in vitro correlates with Microbial adhesion to fibronectin in vitro correlates with production of endocar

18 Torikata C, Villiger D, Kihn C, McDonald JA. Ultrastructural distribution of fibronectin in normal and fibrotic human lung. Lab Invest 1985;52:399-408.

19 Limper AH, Roman J. Fibronectin. A versatile matrix protein with roles in thoracic development, repair and infection. Chest 1992;101:1663-73.

20 Hynes RO. Integrins: a family of cell surface receptors. Cell 1987;48:549-54.

21 Roberts CJ, Birkenmeier TM, McQuillan JJ, et al. Transforming growth factor $B$ stimulates the expression Transforming growth factor B stimulates the expression
of fibronectin and of both subunits of the human of fibronectin and of both subunits of the human fibronectin receptor by cultured

22 Cardarelli PM, Blumenstock FA, Saba TM, Rourke FJ. Fibronectin-enhanced attachment of gelatin-coated erythrocytes to isolated Kupffer cells. $\mathcal{F}$ Leukocyte Bio 1984;36:477-92.

23 Ruoslathi E, Pierschbacher MD. New perspectives in cel adhesion: RGD and integrins. Science 1987;238:491-7.

24 Wiertz EJH, Walvoort HC, Van Loveren H, Van StraatenVan De Kappelle I, Van Der Gun JW, Kreeftenberg JG. Acellular and whole cell pertussis vaccines protect Acellular and two different T-cell dependent humoral routes. Biologicals 1990;18:173-80.

25 Petersen JW, Ibsen PH, Haslov K, Heron I. Proliferative responses and gamma interferon and tumor necrosis factor production by lymphocytes isolated from tracheobroncheal lymph nodes and spleens of mice aeroso infected with Bordetella pertussis. Infect Immun 1992;60:4563-70.

26 Mills KHG, Barnard A, Watkins J, Redhead K. Cell-mediated immunity to Bordetella pertussis: role of Th1 cells in bacterial clearance in a murine respiratory infection model. Infect Immun 1993;61:399-410. 